\title{
Assessment of $M B L 2$ gene polymorphism and lipid peroxidation in Chronic Obstructive Pulmonary Disease (COPD)
}

\author{
Aarti Sharma', Gursatej Gandhi ${ }^{1}$, Jatinder Singh ${ }^{2}$, Sukhdev Singh ${ }^{2}$, Manpreet Kaur ${ }^{1 *}$ \\ From International Conference on Human Genetics and 39th Annual Meeting of the Indian Society of \\ Human Genetics (ISHG) \\ Ahmadabad, India. 23-25 January 2013
}

\section{Background}

Chronic Obstructive Pulmonary Disease (COPD) is fourth leading cause of death worldover. It has been defined as a state characterized by airflow obstruction due to inflammatory reaction. Various innate and adaptive immune system molecules are involved in pathogenesis of COPD. Mannose-binding lectin (MBL) is a $\mathrm{Ca}^{2+}$ dependent collagenous lectin which intervene immune response by inhibiting pathogen activity. Point mutations, in codon 54 and 57 of exon 1 of the MBL2 have been reported to affect the serum levels of MBL. Aim of the present study was to investigate the association of MBL2 gene polymorphism with severity and susceptibility towards COPD.

\section{Methodology}

129 COPD patients and 90 age- and sex-matched controls were recruited for the study. Genomic DNA was isolated from blood samples. PCR-RFLP of codon 54 and 57 of the MBL2 were studied using enzymes BanI and MboII respectively. In addition to this, serum MDA concentrations were evaluated by TBA-TCA-HCl method. Genotypic distribution was compared by odds ratio statistics using medcal software. Differences in MDA concentrations were analyzed by student's ' $t$ ' test using SPSS version 18.0 (IL, USA, and Chicago).

\section{Results}

The genotypic frequencies of codon 54 in COPD patients were significantly higher $(p<0.05)$ than that of controls. GG genotype was found to be more prevalent in cases $(\mathrm{OR}=3.402 ; \mathrm{CI}=1.14-10.10 ; \mathrm{p}<0.05)$. However, there was

\footnotetext{
* Correspondence: dr.manpreetdhuna@gmail.com

${ }^{1}$ Department of Human Genetics, Guru Nanak Dev University, Amritsar, India Full list of author information is available at the end of the article
}

no significant difference in genotypic distribution for codon 57 of MBL2 gene. Serum MDA concentrations were significantly $(\mathrm{p}<0.001)$ higher in patients $(9.00$ $\pm 2.906)$ as compare to controls $(6.31 \pm 2.361)$.

\section{Conclusion}

The results of the present study revealed that MBL2 polymorphism may be involved in pathogenesis of COPD.

\section{Authors' details}

'Department of Human Genetics, Guru Nanak Dev University, Amritsar, India. ${ }^{2}$ Department of Molecular Biology \& Biochemistry, Guru Nanak Dev University, Amritsar, India.

Published: 21 January 2014

doi:10.1186/1755-8166-7-S1-P95

Cite this article as: Sharma et al:: Assessment of MBL2 gene

polymorphism and lipid peroxidation in Chronic Obstructive Pulmonary

Disease (COPD). Molecular Cytogenetics 2014 7(Suppl 1):P95.

Submit your next manuscript to BioMed Central and take full advantage of:

- Convenient online submission

- Thorough peer review

- No space constraints or color figure charges

- Immediate publication on acceptance

- Inclusion in PubMed, CAS, Scopus and Google Scholar

- Research which is freely available for redistribution 